\title{
Effects of intravitreal ranibizumab on the untreated eye and systemic gene expression profile in age-related macular degeneration [Corrigendum]
}

\author{
Michalska-Małecka K, Kabiesz A, Kimsa MW, et al. Clin \\ Interv Aging. 2016;11:357-365.
}

On page 358, Materials and methods, Subjects section. The ethics statement was "The study was approved by the Bioethics Committee of the Medical University in Katowice (KNW) in accordance with the Declaration of Helsinki regarding medical research involving human subjects", the corrected ethics statement is "The study was approved by the Bioethical Committee of Medical University of Silesia (approval number: KNW/0022/KB1/38/I/15) and is consistent with the Declaration of Helsinki".

CAS, Scopus and the Elsevier Bibliographic databases. The manuscript management system is completely online and includes a very quick and fair peer-review system, which is all easy to use. Visit http://www.dovepress. com/testimonials.php to read real quotes from published authors. 